\title{
Saudi national science, technology and innovation plan towards knowledge based economy
}

\author{
Abdulaziz M. Al-Swailem \\ From 2nd International Genomic Medical Conference (IGMC 2013) \\ Jeddah, Kingdom of Saudi Arabia. 24-27 November 2013
}

National Science, Technology and Innovation strategic Plan (NSTIP) is among many other national plans followed in Saudi Arabia to shift its economy from oil based to knowledge based. The National Policy for Science and Technology, approved by the Council of Ministers in 1423 Hijri (2002 G), has defined 15 programs for localization and development of strategic technologies that are essential for the future development of the Kingdom of Saudi Arabia.

NSTIP is mandated to direct science research and technology development in the Kingdom of Saudi Arabia towards long-term development goals of the country. It is also responsible for strengthening ties between key components of the Science and Technology national plan, such as research and development centers, education and training organizations, companies, investors, innovators, technology suppliers, consulting firms and scientific media.

NSTIP also works closely with the education sector to ensure that science and technology education programs are in line with Science and Technology National Policy (STNP) requirements. They both also help in developing programs and institutes for higher studies in applied scientific and technical fields.

NSTIP promotes and develops financial support sources in addition to developing regulations that govern the performance of the policy. It also encourages and increases international cooperation in the development of the science and technology fields and it is responsible for the dissemination and distribution of scientific and technology information.

King Abdulaziz City for Science and Technology (KACST) monitors the implementation of NSTIP, plays a major role in executing the plan, chairs the steering

Correspondence: alswailem@kacst.edu.sa

King Abdulaziz City for Science and Technology (KACST), Riyadh, Kingdom of Saudi Arabia

C) Biomed Central

C 2014 Al-Swailem; licensee BioMed Central Ltd. This is an Open Access article distributed under the terms of the Creative Commons Attribution License (http://creativecommons.org/licenses/by/2.0), which permits unrestricted use, distribution, and reproduction in any medium, provided the original work is properly cited. committee, and publishes reports about the key performance indicators and many governing regulation.

Published: 2 April 2014

doi:10.1186/1471-2164-15-S2-O2

Cite this article as: Al-Swailem: Saudi national science, technology and innovation plan towards knowledge based economy. BMC Genomics 2014 15(Suppl 2):O2.

Submit your next manuscript to BioMed Central and take full advantage of:

- Convenient online submission

- Thorough peer review

- No space constraints or color figure charges

- Immediate publication on acceptance

- Inclusion in PubMed, CAS, Scopus and Google Scholar

- Research which is freely available for redistribution Submit your manuscript at
www.biomedcentral.com/submit C) BioMed Central 